\title{
Insulin-like growth factor II gene Apa I polymorphism is not associated with endometriosis susceptibility
}

\author{
Yao-Yuan Hsieh ${ }^{\mathrm{a}}$, Chi-Chen Chang ${ }^{\mathrm{a}}$, Fuu-Jen Tsai ${ }^{\mathrm{b}}$ Ching-Tien Peng ${ }^{\mathrm{b}}$, Lian-Shun Yeh ${ }^{\mathrm{a}}$, Cheng-Chieh Lin ${ }^{\mathrm{c}}$ \\ ${ }^{a}$ China Medical University Hospital, Department of Obstetrics and Gynecology, Taichung, Taiwan. \\ ${ }^{b}$ China Medical University Hospital, Department of Pediatrics and Medical Genetics, Taichung, Taiwan. \\ ${ }^{c}$ China Medical University Hospital, Department of Family Medicine, Taichung, Taiwan.
}

\begin{abstract}
Insulin-like growth factor II (IGF2) has been shown to play a role in abnormal cell growth and carcinogenesis. We investigated if the IGF2 gene Apa I polymorphism at exon 9 was associated with the susceptibility to endometriosis, analyzing 120 women with moderate/severe endometriosis and 103 controls. The genotype frequencies did not differ statistically between the endometriosis ( $a a=25.4, a b=57.4, b b=17.2 \%)$ and control $(a a=20.8 a b=52.8, b b=$ $26.4 \%$ ) groups. The allele frequencies did not differ either: $a=54.1, b=45.9 \%$ among women with endometriosis and $a=47.2, b=52.8 \%$ in the control group. Therefore, no indication was found for an association of this polymorphism with endometriosis susceptibility.
\end{abstract}

Key words: endometriosis, insulin-like growth factor, $I G F-2$.

Received: November 14, 2001; Accepted: December 18, 2003.

Endometriosis is associated with a complex interaction of immuno-inflammatory processes, cytokine activation, and genetic factors. Endometrial cells synthesize cytokines and growth factors, modulating endometrial proliferation and differentiation (Loverro et al., 1999). Insulin-like growth factor-I (IGF-I) and their receptors were reported to be abnormally expressed in ovarian endometriosis, and may play a role in the pathogenesis of endometriosis. (Loverro et al., 2001). Insulin-like growth factor II (IGF-II) is a 67-amino acid mitogenic peptide, which may act as an autocrine or paracrine growth factor, enhancing and maintaining tumor growth (El-Badry et al., 1991; Kim et al., 1998). In fact, several tumors have been shown to oversecrete IGF-II, e.g. uterine leiomyosarcoma ( $\mathrm{Vu}$ et al., 1995), ovarian cancer (Yun et al., 1996), endometrial cancer (Roy et al., 2000), cervical cancer (Douc-Rasy et al., 1996), breast carcinoma (Wu et al., 1997), and testicular tumors (Nonomura et al., 1997). Heterozygosity for $I G F 2$ Apa I polymorphism at exon 9 was found to be lower in patients with uterine leyomyosarcoma than in heathy subjects (Vu et al., 1995).

As $I G F 2$ gene is involved in cell growth and differentiation, we investigated whether the ApaI polymorphism

Send correspondence to Fuu-Jen Tsai, M.D., Ph.D. China Medical University Hospital, Department of Pediatrics and Medical Genetics, n. 2 Yuh-Der Road, Taichung, Taiwan. E-mail: d0704@ hpd. cmuh.org.tw or d3531@yahoo.com.tw.
$(\mathrm{A} / \mathrm{G})$ at exon 9 of this gene was associated with the disease, predicting susceptibility to endometriosis.

A group of 122 pre-menopausal Taiwan Chinese women with surgically diagnosed moderate/severe endometriosis was studied. .The control group was formed by 106 women whose non-endometriosis status was confirmed during cesarean sections or diagnostic laparoscopy. All surgeries were performed by two of us (Hsieh YY, Chang CC). Informed consent was provided by the patients, and the study was approved by the Ethical Committee of the China Medical University Hospital. The two groups of women did not differ statistically for age $(32.2 \pm 2.6$ vs. $33.4 \pm 3.5$ years $)$, weight $(51.5 \pm 3.8$ vs. $53.2 \pm 4.3 \mathrm{~kg})$ and height $(158.2 \pm 4.6$ vs. $156.4 \pm 3.6 \mathrm{~cm})$.

Genomic DNA was isolated from peripheral blood using Genomaker DNA Extractor kit (Blossom, Taiwan). About $50 \mathrm{ng}$ of genomic DNA was mixed with 20 pmol of each PCR primer in a total volume of $25 \mu \mathrm{L}$ containing $10 \mathrm{mM}$ Tris- $\mathrm{HCl}, \mathrm{pH} 8.3,50 \mathrm{mM} \mathrm{KCl}, 2.0 \mathrm{mM} \mathrm{MgCl}_{2}$, $0.2 \mathrm{mM}$ each deoxyribonucleotide triphosphate, and 1 unit of Amplitaq DNA polymerase (Perkin Elmer Applied Biosystems, Foster City, CA, USA). For the Apa I (A/G) polymorphism analysis (Tadokoro et al., 1991), IGF2 exon 9 was amplified using the primers: upstream, 5'CTTGGA CTTTGAGTCAAATTGGC3' and downstream, 5'GCG GTACGAGCGACGTGCCCAC3'. PCR conditions were as follows: 35 cycles at $95{ }^{\circ} \mathrm{C}$ for $20 \mathrm{~s}, 60^{\circ} \mathrm{C}$ for $20 \mathrm{~s}$, and 
Table 1 - Allele and genotype frequencies of the IGF2 gene Apa I polymorphism in women with or without endometriosis.

\begin{tabular}{cccc}
\hline & $\begin{array}{c}\text { Women with } \\
\text { endometriosis } \\
\mathrm{n}=122\end{array}$ & $\begin{array}{c}\text { Women without } \\
\text { endometriosis } \\
\mathrm{n}=106\end{array}$ & $p$-value \\
\hline $\begin{array}{c}\text { Genotype } \\
\mathrm{aa}\end{array}$ & $31(25.4)^{*}$ & $22(20.8)$ & 0.226 \\
$\mathrm{ab}$ & $70(57.4)$ & $56(52.8)$ & \\
$\mathrm{bb}$ & $21(17.2)$ & $28(26.4)$ & 0.140 \\
Alleles & & & \\
$\mathrm{a}$ & $132(54.1)$ & $100(47.2)$ & \\
$\mathrm{b}$ & $112(45.9)$ & $112(52.8)$ & \\
\hline
\end{tabular}

*numbers in parenthesis $=$ percentage

$72{ }^{\circ} \mathrm{C}$ for $20 \mathrm{~s}$. Complete ApaI digestion (1 unit ApaI in $10 \mu \mathrm{L}$ buffer for $30 \mathrm{~min}$ at $37^{\circ} \mathrm{C}$ ) yielded a single fragment of $100 \mathrm{bp}$ for the "a" allele (not digested by ApaI) or two digestion fragments of 63 and $37 \mathrm{bp}$ for the "b" allele. PCR products were analyzed by electrophoresis on 3\% agarose gel followed by ethidium bromide staining. Genotype and allele frequencies in the two groups were compared by $\chi^{2}$ test.

Genotype and allele frequencies of the IGF2 Apa I polymorphism are shown in Table 1 . The frequencies of aa, $\mathrm{ab}$ and $\mathrm{bb}$ genotypes did not differ significantly between women with or without endometriosis, and the allele frequencies were not significantly different either. The observed genotype frequencies in both groups did not deviate significantly from Hardy-Weinberg equilibrium proportions. As previously reported by Chen et al. (2003), the frequency of both alleles was found to be high in our population, and about half of the individuals were heterozygous.

In conclusion, our investigation did not detect an association between the IGF2 gene Apa I polymorphism and endometriosis in our population.

\section{References}

Chen WC, Chen HY, Wu HC, Wu MC, Hsu CD and Tsai FJ (2003) Vascular endothelial growth factor gene polymor- phism is associated with calcium oxalate stone disease. Urol Res 31:218-22.

Douc-Rasy S, Barrois M, Fogel S, Ahomadegbe JC, Stehelin D, Coll J and Riou G (1996) High incidence of loss of heterozygosity and abnormal imprinting of $H 19$ and $I G F 2$ genes in invasive cervical carcinomas. Uncoupling of $H 19$ and IGF2 expression and biallelic hypomethylation of $H 19$. Oncogene 12:423-30.

El-Badry OM, Helman LJ, Chatten J, Steinberg SM, Evans AE and Israel MA (1991) Insulin-like growth factor II-mediated proliferation of human neuroblastoma. J Clin Invest 87:648-57.

Kim HT, Choi BH, Niikawa N, Lee TS and Chang SI (1998) Frequent loss of imprinting of the H19 and IGF-II genes in ovarian tumors. Am J Med Genet 80:391-5.

Loverro G, Maiorano E, Napoli A, Selvaggi L, Marra E and Perlino E (2001) Transforming growth factor-beta 1 and insulin-like growth factor-1 expression in ovarian endometriotic cysts: a preliminary study. Int J Mol Med 7:423-9.

Loverro G, Perlino E, Maiorano E, Cormio G, Ricco R, Marra E, Nappi L, Giannini T and Selvaggi L (1999) TGF-beta 1 and IGF-1 expression in atrophic post-menopausal endometrium. Maturitas 31:179-84.

Nonomura N, Miki T, Nishimura K, Kanno N, Kojima Y and Okuyama A (1997) Altered imprinting of the H19 and insulin-like growth factor II genes in testicular tumors. J Urol 157:1977-9.

Roy RN, Gerulath AH, Cecutti A and Bhavnani BR (2000) Loss of IGF-II imprinting in endometrial tumors: overexpression in carcinosarcoma. Cancer Lett 153:67-73.

Tadokoro K, Fujii H, Inoue T and Yamada M (1991) Polymerase chain reaction (PCR) for detection of $A p a \mathrm{I}$ polymorphism at the insulin like growth factor II gene (IGF2). Nucleic Acids Res 19:6967.

Vu TH, Yballe C, Boonyanit S and Hoffman AR (1995) Insulin-like growth factor II in uterine smooth-muscle tumors: maintenance of genomic imprinting in leiomyomata and loss of imprinting in leiomyosarcomata. J Clin Endocrinol Metab 80:1670-6.

Wu HK, Squire JA, Catzavelos CG and Weksberg R (1997) Relaxation of imprinting of human insulin-like growth factor II gene, IGF2, in sporadic breast carcinomas. Biochem Biophys Res Commun 235:123-9.

Yun K, Fukumoto M and Jinno Y (1996) Monoallelic expression of the insulin-like growth factor-2 gene in ovarian cancer. Am J Pathol 148:1081-7.

editor Associado: Angela M. Vianna-Morgante 